\title{
Community Perceptions of Free-Roaming Dogs and Management Practices in Villages at the Periphery of a Protected Area in Bhutan
}

\author{
Tshering Dorji ${ }^{1,2}$, Tenzin Tenzin ${ }^{3}$, Karma Rinzin ${ }^{4}$, \\ Waraphon Phimpraphai ${ }^{1}$, and Michel de Garine-Wichatitshy ${ }^{1,5,6^{*}}$
}

${ }^{1}$ Faculty of Veterinary Medicine, Kasetsart University, Bangkok 10900, Thailand ${ }^{2}$ Department of Livestock, District Veterinary Hospital, Gasa, Bhutan

${ }^{3}$ Department of Livestock, National Centre for Animal Health, Thimphu, Bhutan

${ }^{4}$ Department of Livestock, Animal Health Division, Thimphu, Bhutan

${ }^{5}$ CIRAD, UMR ASTRE, Montpellier, France

${ }^{6}$ ASTRE, University Montpellier, CIRAD, INRA, Bangkok 10900, Thailand

*Corresponding author. E-mail: degarine@cirad.fr

https://doi.org/10.12982/CMUJNS.2020.00020

Received: April 17, 2019

Revised: July 1, 2019

Accepted: August 19, 2019

\begin{abstract}
In Bhutan, free-roaming dogs pose health hazards to human, livestock, and wildife. Understanding the perceptions and practices of local communities regarding free-roaming dogs is important to mitigate negative impacts. A community-based study was conducted in the buffer zone of Strict Nature Reserve, western Bhutan. The study was conducted in February-October 2018 using a household questionnaire survey, 'free-listing' of dog diseases, group discussions and key-informant interviews. A total of 140 households from Katsho and Esue geogs (sub-districts) were interviewed. People classify dogs under three categories: 'Gokhi'/pet dog, 'Changkhi'/stray dog, and 'Shakhi'/feral dog. A higher proportion of rural people owned pet dogs, which were considered important to guard crops and livestock from wildlife and protect households' properties. Owning a dog also contributed significantly to the non-material well-being of the respondents, especially in the rural villages. In contrast to the perceived positive impacts of the pet dogs, $81 \%$ of the respondents considered stray and feral dogs a problem in the community. The threats were attacks/bites by free-roaming dogs to humans, livestock and also wildlife. Rabies was the most frequently (69.7\%) known dog diseases with the highest rank (1.46) in the list, followed by scabies (49.5\%, rank 1.52). The majority (56\%) of the respondents indicated that stray and feral dogs originate from abandoned pet dogs. This study calls for a multi-sectorial/One Health
\end{abstract}




\section{approach to mitigate the threats posed by free-roaming dogs and more detailed ecological and epidemiological studies are required to control their impacts.}

Keywords: Free-roaming dogs, Perceptions, Livestock, Protected areas, Bhutan

\section{INTRODUCTION}

The dog (Canis familiaris) is currently one of the most widespread human commensals throughout the world (Larson and Burger, 2013). Dogs provide a number of material and non-material services to people such as, being a pet or a guide for the blind people, guarding livestock, crops and properties, assisting in hunting and search-rescue operations (Woodward, 2001; Winkle et al., 2012; Blouin, 2013). Based on the dependency of dogs to humans for food and shelters, they can be classified as, i) 'pet dogs', which completely depend on humans for food and are confined at least part of the time, ii) 'free-roaming dogs' that depend on humans in part of their food supply only, and iii) 'feral dogs' which are completely independent from humans (Slater et al., 2008; Blouin, 2013). Beside many positive aspects of the domestic dogs, there are some negative impacts for public health, livestock and wildlife health, especially in areas where uncontrolled dog populations roam freely (Boitani and Ciucci, 1995; Slater, 2004; Young et al., 2011; Acosta-Jamett et al., 2015). Including rabies more than sixty zoonotic diseases are associated with dogs (Macpherson et al., 2000; Czupryna et al., 2016). Dogs also threaten endangered wildlife species through predation and transmission of infectious diseases such as canine distemper virus (Hughes and Macdonald, 2013; Sepúlveda et al., 2015; Ward et al., 2015; Lessa et al., 2016)

Bhutan has more than $70 \%$ of the territory under forest cover and human settlements are located within the forests, inside the national parks' boundaries and also in buffer zones of the parks (Choden, 2016). There are large numbers of free-roaming dogs in the country and they are associated with human settlement and urbanization (Tenzin et al., 2012). Dog mediated rabies has been identified as one of the main zoonotic disease that pose public health risk in Bhutan (Tenzin et al., 2011; Tenzin and Ward, 2012). Besides, sero-positivity to Canine Distemper Virus, Canine Parvo Virus and Canine Leptospira has been documented in domestic dogs in Thimphu city area (Rinzin, 2015), although no dog-mediated diseases have been reported in wildlife to date (Dorji et al., 2011). Therefore, understanding the ecological and epidemiological impacts of domestic and feral dogs at human-livestock-wildlife interfaces, including disease transmission risks and community knowledge, attitude and practices on dogs within the protected areas, is important for making science-based policy decisions. This paper reports the results of a survey on the community knowledge, perceptions and practices in rural and semi-urban communities towards dogs and their negative impacts in the periphery of Haa Jigme Khesar Strict Nature Reserve, Western Bhutan. 


\section{MATERIALS AND METHODS}

\section{Site selection}

The study sites are at the periphery of Jigme Khesar Strict Nature Reserve (JKSNR), in Haa Dzongkhag (District), located in western part of Bhutan (Figure 1). This protected area was created in 1993 by the Royal Government of Bhutan. This is the only protected area without permanent human settlements in Bhutan, except for few migratory yak herding communities. A total of 29 species of mammals, 161 species of birds, 64 species of butterfly and seven species of fish have been recorded within this park boundary. It is home to endangered species such as the Snow Leopard (Panthera uncial), Red Panda (Ailurus fulgens), Tibetan Snow cock (Tetraogallus tibetanus) and Rufous Necked Hornbill (Aceros nipalensis). It is also part of the transboundary conservation landscape -the Kangchenjunga landscape - that extends up to Sikkim in India and Nepal. There are six geog (sub-districts) under Haa Dzongkhag and we selected one semi-urban geog (Katsho, Haa town) and one adjacent rural gewog (Esue) for this study (Figure 1). The people in these geogs keep domestic yaks that are grazed within the strict nature reserve area.

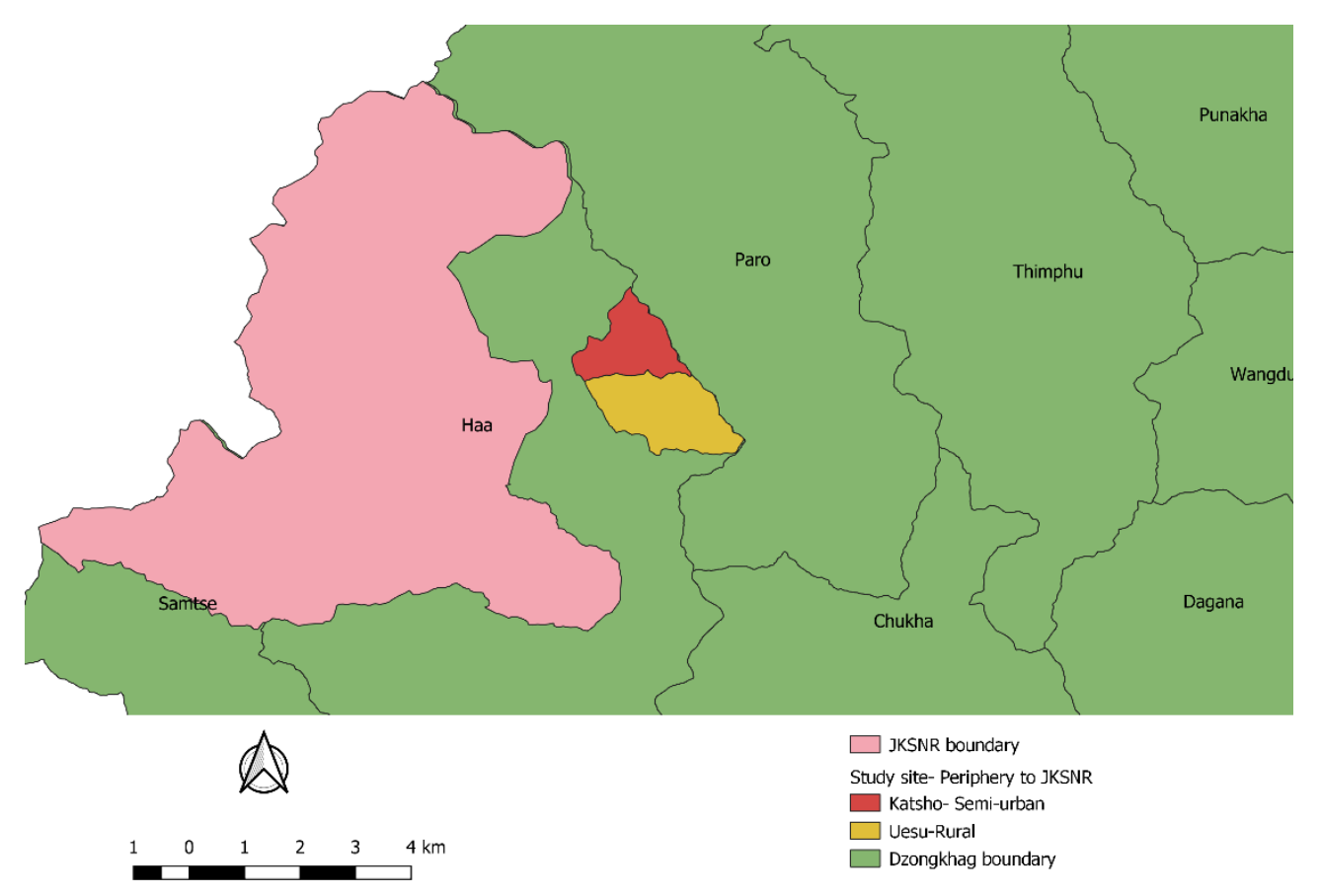

Figure 1. Location of Jigme Khesar Strict Nature Reserve and the periphery villages of Katsho/semi-urban and Esue/rural Geogs-the two study area under Haa Dzongkhag, Western Bhutan. 


\section{Study design and data collection}

There are 455 officially registered households (hh) in the two study geogs: 250 in Esue and 255 in Katsho (PHCB Haa Dzongkhag, 2017). We calculated the minimum sample size by assuming a response distribution of $50 \%$ with a $10 \%$ margin error and 95\% confidence level, and obtained the sample size of 70 hh each from Esue and Katsho. The survey included combination of questionnaire-based interview of the selected household, key informant interviews and group discussion.

The questionnaire were developed with a combination of both closed and open-ended questions and were organized into six sections: respondents characteristics, livestock population dynamics, dog ownership and population management, dog ecology and impacts, dog health and management, and feral dog related issues. The questionnaire also contained a free-listing of the names of dog disease known by the informants (Borgatti, 1999) in order to explore knowledge among the respondents regarding dogs health and their epidemiological impacts. A questionnaire was piloted in the study area - Haa - in February 2018 with 16 farmers and then modified accordingly to improve clarity of some of the questions.

The actual field survey was conducted by visiting the household in each selected village based on the recommendations of the district veterinary hospital officials and then used 'snowball' techniques for selecting the subsequent respondents in the village until the required number of samples were selected and interviewed (Goodman, 1961).

One adult person (>18 years of age) from each selected household was interviewed face-to-face by the first author and trained research assistants. An informed consent was obtained from the respondents prior to the interview. The interview was done in local language - Dzongkha - but translated and recorded in English since the questionnaire was developed in English. Each selected adult respondent was informed about the aims and objectivies of the study and all individuals have agreed to participate in the survey. The questions related to the perception of the ecology and epidemiology of free-roaming dogs were asked to all the respondents irrespective of whether they owned dogs or not, but the questions related to the pet management practices were asked only to the dog owners.

A group discussion was organized in each study site to explore people's perception regarding dog ecology, epidemiology and associated problems and solutions (vernacular names of diseases, perception of movements and behavior). The participants for the group discussion included geog leaders (Gup and Mangmi), village headman (Tshogpa), and the civil servants working in the geogs, forest officials from the JKSNR and the livestock officials of Haa District. The community also classified and categoried various types of dogs during the 
group discussion. A participatory mapping exercise in each study sites was also performed to identify preferred dogs habitats and associated dog problems.

In addition to household interviews and group discussions, an in-depth interviews were conducted with three male and two female local veterinary staffs working in Haa; two male park officials, and two male and three female elders. One women, the local spiritual healers (Nyeljorm) from Esue and one male buddhist astrologer/monk (Tsip) from Katsho were also interviewed on livestock diseases and the treatment methods. All interviews and the group discussions were carried out between February and May 2018. The study was approved by the Bhutan Livestock Research ethic board committee vide letter No DoL/Gen/RED/2017-18/056/Feb-11/18.

\section{DATA MANAGEMENT AND ANALYSIS}

Data were entered, cleaned and managed within a Microsoft Excel database (Microsoft Excel 2013, USA) and were analyzed with R statistical software version 3.5 using the packages 'dplyr', 'descry', 'focasts', 'Imtest', 'LogisticDx', and 'ggplot2' (R core Team, 2017). We have categorized the age into 18-30, 3160 and $>60$ years; education level as educated and uneducated, occupation as farmer and non-farmer. Descriptive statistics were performed to calculate proportions, frequency, mean, median, standard deviation, range and maximum values for categorical and continuous variables. The frequencies of the categorical variables between two communities were compared using Pearson's Chi-square test. We used the parametric Student's $t$ test for comparison of the mean age of respondents and mean age of dogs, and the Non-parametric Wilcoxson/ Manwhitney tests for continuous variables (du Prel et al., 2010; Dexter, 2013).

First, a univariable logistic regression analysis was performed to assess the association between the socio-demographic variables of respondents (age, gender, education level, occupation and position of household) and the demographic variables of the dogs (age, sex, breed, sources of origin, neuter status) as an independent factor to determine the binary outcome on variables 1) perception on importance of dogs (yes vs no), 2) practices of confining dogs through proper housing (yes vs no), 3) perception on roaming of pet dogs (yes vs no), 4) practices on pet management through vaccination (yes vs no), 5) Fear against free-roaming dogs $(y e s / n o)$. Those variables with $(P<0.25)$ from the univariable logistic regression analysis were selected for the multivariable logistic regression analysis. The final best fit models were constructed using forward stepwise elimination method based on the AIC (Akakai Information Criterion) and residual. Any variables with $P$-value of $<0.05$ were considered significant and retained in the final model.

The free-lists of dog diseases names were analysed using software FLAME1.1 (Pennec et al., 2014). We calculated and ranked each disease list cited 
by the respondent as the Sutrop index, a measure of the salience based on the frenquency of citation and the mean rank of citation (Borgatti, 1999).

\section{RESULTS}

Socio-demographic characteristics

A total of 140 respondents were interviewed, 70 each from Esue (rural) and Kartso (town). The female respondents (57.5\%) represented a slightly higher proportion than males $(42.5 \%)$ and the participants' ages ranged from 18 to 84 year with a mean of 45.8 years. The position occupied in the household among the participants were mother $(41 \%)$, father $(34 \%)$, son/daughter $(24 \%)$ and inlaws $(4 \%)$. The distribution of the respondent's occupation was slightly different between rural and town, with higher proportion of respondents being farmers in Esue and more civil servants/corporate workers and the business/contractors in Katsho. On average there were 4.1 people living in the households at the time of the survey.

Table 1. Socio-demographic characteristics of respondents in the two study sites (Esue/Rural, Katsho/semi-urban).

\begin{tabular}{lcc}
\hline Variables & Esue/rural n (\%) & Katsho/semi-urban n (\%) \\
\hline Gender & $30(43)$ & $29(41)$ \\
Male & $40(57)$ & $41(59)$ \\
Female & & \\
\hline Age(years) & $8(11)$ & $\mathrm{n}(29)$ \\
$18-30$ & $34(49)$ & $28(40)$ \\
$31-60$ & $28(40)$ & $22(31)$ \\
$>61$ & & \\
Qualification/education level & $29(42)$ & $36(51)$ \\
No schooling & $12(17)$ & $1(1.5)$ \\
Non-Formal Education & $11(15)$ & $3(4)$ \\
Primary school (class $<=6)$ & $1(1.5)$ & $4(6)$ \\
Lower secondary school (class $<=8)$ & $4(6)$ & $15(22)$ \\
Higher secondary school (class $<=12)$ & $1(1.5)$ & $10(14)$ \\
Degree level or higher & $12(17)$ & $1(1.5)$ \\
Monastic education & & \\
Occupation & $59(84)$ & $39(56)$ \\
Farmer & $2(3)$ & $12(17)$ \\
Civil servant/Corporate worker & $3(4)$ & $0(0)$ \\
Military & $2(3)$ & $5(7)$ \\
Student & $1(1.5)$ & $1(1.5)$ \\
Monk/Gomchen/Nun & $1(1.5)$ & $11(15.5)$ \\
Business/Contractor & $2(3)$ & $2(3)$ \\
Others & &
\end{tabular}

\section{Impact of dog ownership on self-assessed happiness and health status}

More than $50 \%$ of the respondents in both the study site mentioned that they were « very happy »(Esue 57\%, Katsho 51\%) or 'moderately happy' 
(Esue 40\%, Katsho 46\%), and only 3\% 'Not happy at all'. However, in the absence of dog (i.e. 'if you had no dog'), the score of happiness of the respondents decreased sharply with lower proportions of persons rating 'very happy' (Esue 9\%, Katsho 37\%) and moderately happy (Esue 37\%, Katsho $36 \%$ ), and higher proportions rating their score as 'Not at all happy' (Esue 54\%, Katsho 27\%) (Figure 2). The proportion of people who would be 'not happy at all' without a dog was higher in Esue community than semi-urban (Wilcoxon test=14035, $P<0.05$, 95\% CI (1.9-2.9). Self-assessed health status by the respondents in absences of pet dogs between two communities were significant (Wilcoxon test=19320, $P<0.05$, 95\%CI (6.9-7.0). The majority of the respondents considered that they were very healthy (Esue $68.5 \%$ and Katsho $78 \%$ ) or moderately healthy (Esue $30 \%$, Katsho $16 \%$ ), whereas only a small min ority indicated that they were not at all healthy in absences of pet dogs (Esue 1.5 $\%$, Katsho 6\%).

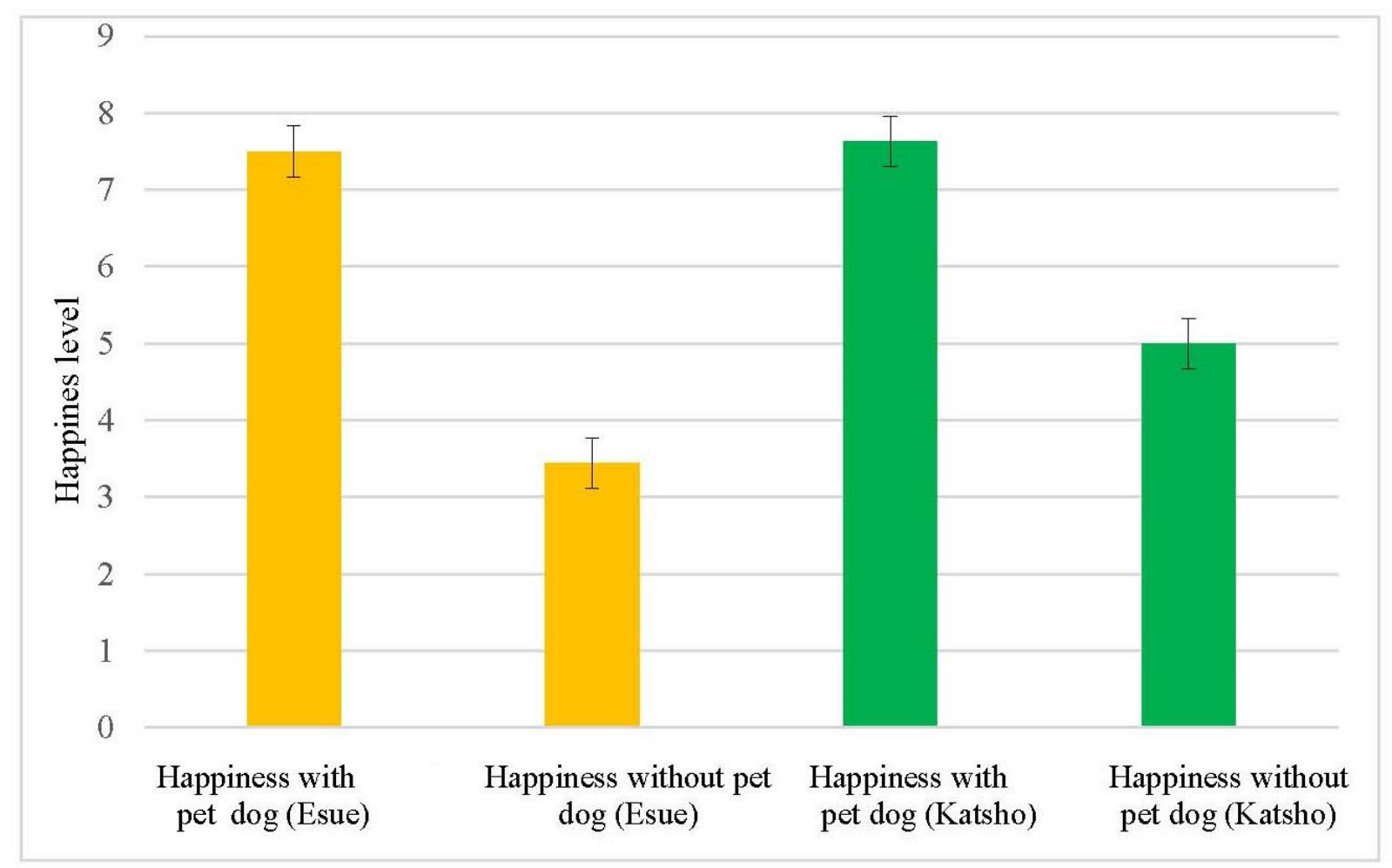

Figure 2. Mean score of apiness level (0-10) scale among the respondent between Esue and Katsho with and without pet dogs with standard me an error $(n=70)$ from both the study sites.

\section{Livestock population dynamics and the cause of death for one year}

During the one year period before the survey, farmers reported that approximately $(10 \%)$ of the cattle population had died due to various causes: diseases (31\%), unknown causes (21\%), accident (19\%), magic causes 
'Dhoe/Dre' (18\%), predation by wildlife (7\%) and killed by domestic dogs (4\%). During the same period, the death rate of domestic dogs reported by dog owners was approximately (4\%) of the dog population. The major cause for the death of pet dogs was attacks by other free-roaming dogs (58\%), and wildlife predation, accident and diseases (14\%). The death rate of pet cats by dog predation was $(50 \%)$ and the rest were due to diseases and unknown. Unlike cattle, the death due to magical cause in other domestic species were not mentioned. During the in-depth interviews, the spiritual healers (Nyeljorms) and the astrologer (Tsip) clarified these magical causes broadly including the outcome of encountering with spirits and invisible powers. These evil spirits cause harm when people have disturbed or harmed them. The informants indicated that the following evil spirits could cause harm: the spirit of the death of human (Shindre), the spirits of the living soul/human (Soendray), the spirit of the local and the environment (Sadhag Zhidhag), the spirit of the local deities of the birth place (Kilha/Tsoen), the spirit of ghost (Dhoe), and spirit of 'Mermaid' and the water bodies (Tshomen and Lug). All the species of animals are bound to get sick and die because of these evil spirits, but the local healers are consulted for the treatment of cattle only, and they suspected that this was probably because of their higher economic importance compared to other livestock. The spirits of Lug and Soendray are the two most common in the area, and also the most difficult to treat not only in cattle but also in human. The diseases which are described as 'cancer' and 'tumor' are often due to the spirits of Lug.

\section{Dog ownership, management and classification}

Community member classify dogs based on ownership into two main groups: 'owned dogs (Jodha yoeme)' vs 'not owned dogs (Jodha meyme)', the later including 'stray (Chankhi)' and 'feral (Shakhi)' dogs. The pet dogs are considered under owned dog group and specifically termed as 'Gokhi (door dog)'. A higher proportion of households in Esue owned pet dog (77\%) compared to Katsho $(59 \%)\left(\chi^{2}=5.5345, \mathrm{df}=1, P=0.01\right)$. Higher porportion of respondents in Esue considered that dogs were important in their lives $\left(\chi^{2}=6.9662\right.$, $\mathrm{df}=1$, $P=0.008$ ), especially to guard their livestock. Dog owners from both study sites usually keep one or two dogs, although up to five dogs were recorded for the same owner in Esue. Esue respondents owned a higher proportion of local undefined/cross-breeds (Changkhi), whereas Katsho respondents had a higher proportion of pure breeds, including the Mastiff, Labrador, Golden retriever, Beagle, Pomeranian, Spitz and German shepherd. However, there was no difference in the source from which the dogs were obtained $\left(\chi^{2}=6.9685\right.$, $\mathrm{df}=5$, $P=0.2$ ), most commonly through adoption of stray/free-roaming dogs, or received as a gift (of unknown origin).

Dog management practices appeared very similar between the two study areas (Table 2), except for dog health care and housing. Although most respondents from both the study sites mentionned that their dogs were vaccinated 
against rabies, only few had vaccinated their dogs against Canine Distemper, and treated for scabies and given vitamin injection. The dogs from the semi-urban area (Katsho 76\%) had a slightly higher percentage of vaccination than rural area $(70 \%)\left(\chi^{2}=5.8503, \mathrm{df}=1, P=0.05\right)$. However, there were some differences between the two study areas regarding the actions taken when their dogs became sick. For instance $(22 \%)$ of the respondents from Katsho and (9\%) from Euse mentioned that they would do nothing when their dogs became sick whilst (52\%) and $(30 \%)$ of the owners from Katsho and Euse respectively, would either take dogs to veterinary services or get medicines from the veterinary services. The percentage of dogs provided with their own shelter in Esue (43\%) was significantly lower than in Katsho (66\%), however, the types of housing (kennel, open shelter $)$ in both study areas were the same $\left(\chi^{2}=2.2679, \mathrm{df}=1, P=0.13\right)$.

The management of dog reproduction and population control was similar between the two communities. Most of the owners in Esue (60\%) and Katsho $(63 \%)$ did not apply any reproduction control on their dogs, either because their dog was a male or neutered. The management of puppies was very similar between Esue and Katsho, as more than 3/4 of puppies born in a household were given to others, although a significant proportion were abandoned to become stray dogs (15\% in Esue and 13\% in Katsho). Only 1 in 20 respondents from Esue had sold puppies to others, while none of the respondents from Katsho had sold their puppie. More than $90 \%$ of the respondent from both communities $\left(\chi^{2}=0.091146, \mathrm{df}=1, P=0.7\right)$ had heard of the government coordinated dog population control program called Catch Neuter Vaccinate and Release (CNVR) and there was no difference between the two study sites in their willingness to support the program $\left(\chi^{2}=0.098661\right.$, $\left.\mathrm{df}=1, P=0.75\right)$. The minority of respondents who were not willing to support the CNVR program invoked their religious belief that it is a sin to neuter dogs in Esue, while people in Katsho mentioned the difficulties to catch stray dogs for CNVR campaign and requested that the government should use better catching methods. 
Table 2. Reasons for keeping pet dogs and management practices between Esue (rural) and Katsho (semi-urban) Frequency of response (n, \%), significance of $\chi^{2}$ or student $t$ test.

\begin{tabular}{|c|c|c|c|}
\hline Questions & $\begin{array}{c}\text { Esue/rural } \\
\text { n=70 }(\%)\end{array}$ & $\begin{array}{c}\text { Katsho/semi- } \\
\text { urban } n=70(\%)\end{array}$ & $X^{2}$ or t-test \\
\hline \multicolumn{4}{|l|}{$\begin{array}{l}\text { Number of respondents with at least } 1 \\
\text { dog in the household? }\end{array}$} \\
\hline Yes & $54(77)$ & $41(59)$ & \multirow[b]{2}{*}{$* *$} \\
\hline No & $16(23)$ & $29(41)$ & \\
\hline \multicolumn{4}{|l|}{ Is your dog important for you? } \\
\hline Yes & $58(83)$ & $43(61)$ & \multirow[b]{2}{*}{$* * *$} \\
\hline No & $12(17)$ & $27(39)$ & \\
\hline \multicolumn{4}{|l|}{ Reasons for keeping dogs: } \\
\hline To guard agriculture crops & $41(76)$ & $27(66)$ & \multirow[t]{3}{*}{$*$} \\
\hline To guard livestock & $24(44)$ & $11(27)$ & \\
\hline To guard houses and premises & $47(87)$ & $36(88)$ & \\
\hline \multicolumn{4}{|l|}{ Number of dogs owned by the owners } \\
\hline 1 & $22(41)$ & $19(46)$ & \multirow{5}{*}{$* *$} \\
\hline 2 & $16(30)$ & $14(37)$ & \\
\hline 3 & $8(15)$ & $3(7)$ & \\
\hline 4 & $4(7)$ & $2(5)$ & \\
\hline 5 & $4(7)$ & $2(5)$ & \\
\hline \multicolumn{4}{|l|}{ Dog kennel/house availability } \\
\hline Yes & $23(43)$ & $27(66)$ & \multirow[t]{2}{*}{$* * *$} \\
\hline No & $31(57)$ & $14(34)$ & \\
\hline \multicolumn{4}{|l|}{ Types of housing available } \\
\hline Separate and proper dog house/kennel & $19(35)$ & $15(37)$ & \multirow{3}{*}{ NS } \\
\hline Inside the rooms like family members & $2(4)$ & $7(17)$ & \\
\hline $\begin{array}{l}\text { Stay within the premises of the owners } \\
\text { house }\end{array}$ & $33(61)$ & $19(46)$ & \\
\hline \multicolumn{4}{|l|}{$\begin{array}{l}\text { What dog owners do when they have } \\
\text { many puppies? }\end{array}$} \\
\hline $\begin{array}{l}\text { Keep and rear all puppies } \\
\text { themselves }\end{array}$ & $5(25)$ & $5(34)$ & \multirow{4}{*}{ NS } \\
\hline Give some puppies to others & $11(55)$ & $8(53)$ & \\
\hline Sell puppies to others & $1(5)$ & $0(0)$ & \\
\hline $\begin{array}{l}\text { Release to roam the village/street } \\
\text { and become stray dog }\end{array}$ & $3(15)$ & $2(13)$ & \\
\hline
\end{tabular}

Note: Significance code $\left(\chi^{2}\right.$ and $t$ test): NS $P>0.05, * P<0.05$, ** $P<0.01, * * * P<0.001$ 
Table 2. (Continued).

\begin{tabular}{|c|c|c|c|}
\hline $\begin{array}{l}\text { Heard Catch Neuter Vaccinate an } \\
\text { Release of dogs } \\
\qquad \begin{array}{l}\text { Yes } \\
\text { No }\end{array} \\
\end{array}$ & $\begin{array}{c}65(93) \\
5(7) \\
\end{array}$ & $\begin{array}{c}63(90) \\
7 \quad(10) \\
\end{array}$ & NS \\
\hline $\begin{array}{c}\text { Willingness to support Catch Ne } \\
\text { Vaccinate and Release of dog } \\
\text { Yes } \\
\text { No }\end{array}$ & $\begin{array}{c}64(91) \\
6(9)\end{array}$ & $\begin{array}{c}65(93) \\
5(7) \\
\end{array}$ & NS \\
\hline $\begin{array}{l}\text { Reasons not to support Catch Neu } \\
\text { Vaccinate and Release of dogs } \\
\text { Religious belief/ sin to sterilize } \\
\text { It's the government duty to sterilize } \\
\text { No time to support the sterilization } \\
\text { program } \\
\text { Others }\end{array}$ & $\begin{array}{c}3(50) \\
2(33) \\
1(17) \\
0(0)\end{array}$ & $\begin{array}{c}0(0) \\
12(0) \\
2(40) \\
2(40)\end{array}$ & NS \\
\hline $\begin{array}{l}\text { Actions when the dog is sick } \\
\text { Take dog to veterinary hospital for } \\
\text { treatment } \\
\text { Go to veterinary hospital and bring } \\
\text { medicine only } \\
\text { Perform local rituals } \\
\text { Perform local treatments at home } \\
\text { Do nothing } \\
\text { Others }\end{array}$ & $\begin{array}{l}28(52) \\
16(30) \\
0(0) \\
2(4) \\
5(9) \\
3(5)\end{array}$ & $\begin{array}{c}20(49) \\
10(24) \\
0(0) \\
2(5) \\
9(22) \\
0(0)\end{array}$ & $*$ \\
\hline $\begin{array}{l}\text { Vaccinated the dogs last one year } \\
\qquad \begin{array}{c}\text { Yes } \\
\text { No }\end{array}\end{array}$ & $\begin{array}{l}38(70) \\
16(30)\end{array}$ & $\begin{array}{l}31(76) \\
10(24)\end{array}$ & $*$ \\
\hline $\begin{array}{l}\text { Dog breed among the dog owners } \\
\text { Local/ non descriptive } \\
\text { Exotic/ Improved breed }\end{array}$ & $\begin{array}{l}\mathbf{n}=\mathbf{1 1 4} \\
79(69) \\
35(31)\end{array}$ & $\begin{array}{c}\mathbf{n}=74 \\
45(60) \\
29(39)\end{array}$ & $*$ \\
\hline $\begin{array}{l}\text { Sources of dogs } \\
\text { Offspring from owned dogs(self) } \\
\text { Gift from others } \\
\text { Purchased from within Bhutan } \\
\text { Purchased from outside Bhutan } \\
\text { Adopted from stray/free-roaming }\end{array}$ & $\begin{array}{l}\mathbf{n}=\mathbf{5 4} \\
4 \quad(7.2) \\
15(28) \\
14(26) \\
1 \quad(1.8) \\
20(37)\end{array}$ & $\begin{array}{c}\mathbf{n}=\mathbf{4 1} \\
4(9) \\
10(25) \\
8(20) \\
2(5) \\
17(41)\end{array}$ & NS \\
\hline
\end{tabular}

Note: Significance code $\left(\chi^{2}\right.$ and $t$ test): NS $P>0.05, * P<0.05$, ** $P<0.01$, *** $P<0.001$ 


\section{Impacts of free-roaming dogs towards human, domestic animal and wildlife}

A slightly higher proportion of owners indicated that their dogs were roaming freely in Esue $(65 \%)$ compared to Katsho $(59 \%)\left(\chi^{2}=5.9175\right.$, df $=1$, $P=0.05)$. The great majority of the respondents in both sites believed that their dog would remain within $1.0 \mathrm{~km}$ from their home during the day time $(83 \%$ in Esue and $84 \%$ in Katsho), although a higher proportion in Esue believed that their dog could travel long distances greater than $5 \mathrm{~km}$ from home. The patterns of dog movement estimates by owners were almost identical between the day and night for the two study sites (Figure 3). From the binary logistic regression model, the dogs without designated shelter were most likely to roam than those having dog kennel $(P=0.01)$, whereas the other explanatory variables such as breed, age, source of dog, and geog were not significant.

The majority of owners from Esue rural villages believed that their dogs shared habitat with wildlife occasionally $(41 \%)$ or daily $(17 \%)$ and $19 \%$ believed that their dogs never shared habitat with wildlife, whereas $(23 \%)$ did not know. The results were significantly different in Katsho $\left(\chi^{2}=9.9914\right.$, df $=3$, $P=0.01$ ) where only $22 \%$ and $11 \%$ believed that their dog shared daily or occasionally habitat with wildlife, $(36 \%)$ believed that they never did, and $31 \%$ did not know. The most common wild animals mentioned as interacting with dogs were the wild boar ('Riphag'; Sus scrofa) and Barking deer ('Kasha'; Muntiacus muntjak), followed by Sambar deer ('Shaw'; Cervus unicolor). Participants indicated that the interactions between wildlife and dogs happened mostly when the wild animals entered the crop fields, and hence the interactions were mostly located at the periphery of the village settlement and near the crop fields.

Most of the participants in the survey (81\%) agreed that there were problems in the community because of free-roaming dogs. The risks mentionned as being associated with dogs were: bite/attack on a humans (64\%), bite/attack on domestic animals (50\%), bite/attack on wildlife, transmission of diseases to human, transmission of diseases to wildlife, causing nuisance because of barking, environmental contamination with feces and agricultural crop destruction. The majority of respondents rated that they are extremely afraid of dogs in the area (35\%), very afraid (30\%) or moderately afraid (15\%), whereas only $12 \%$ were little afraid and $8 \%$ not afraid at all of these dogs. From the logistic regression, female respondents were more likely to express a high level of fear of dogs than males $(P=0.0001)$ and the fear against free-roaming dogs was similar between Katsho and Esue. The most commonly reported wild and domestic animal species killed by dogs in the previous year were sambar deer, barking deer, wild pig, cattle calf/Boochu and poultry/Bjam. Secondary information provided by Jigme Khesar head-office on yearly statistics of wildlife rescued from dog attacks in 2017 confirmed that the most common wildlife species rescued were sambar deer (74\%), barking deer (21\%), 
and the Himalayan black bear Ursus thibetanus/'Ladhom' (5\%). Parks officials speculated that these figures were understimates as there was no proper reporting system for these incidents in the rural area.

Table 3. Perceptions regarding free-roaming dogs attacks on wildlife and domestic animals in Esue (rural) and Katsho (semi-urban) villages. Frequency and proportions of answers at each site, and significance of $\chi^{2}$ tests to compare between the two sites.

\begin{tabular}{|c|c|c|c|}
\hline Questions & $\begin{array}{l}\text { Esue/rural } \\
(\mathrm{n}=70) \%\end{array}$ & $\begin{array}{l}\text { Katsho/semi-urban } \\
(n=70) \%\end{array}$ & $X^{2}$ or t-test \\
\hline \multicolumn{4}{|l|}{$\begin{array}{l}\text { Do dogs attack on } \\
\text { wildlife? }\end{array}$} \\
\hline Yes & $(\mathrm{n}=50) 71$ & $(n=31) 44$ & \\
\hline No & $(n=13) 19$ & $(n=23) 33$ & $* *$ \\
\hline Don't Know & $(n=7) \quad 10$ & $(n=16) 22$ & \\
\hline \multicolumn{4}{|l|}{$\begin{array}{l}\text { Do dogs attack domestic } \\
\text { animals? }\end{array}$} \\
\hline Yes & $(n=49) 70$ & $(n=28) 40$ & \\
\hline No & $(\mathrm{n}=19) 27$ & $(\mathrm{n}=31) 41$ & \\
\hline Don't Know & $(n=2) \quad 2$ & $(n=11) 16$ & $* *$ \\
\hline \multicolumn{4}{|l|}{$\begin{array}{l}\text { What types of dogs attack } \\
\text { wildlife? }\end{array}$} \\
\hline Owned/pet dog & $(n=5) \quad 7$ & $(\mathrm{n}=1) \quad 1$ & \\
\hline Stray dogs & $(n=29) 41$ & $(n=22) 32$ & \\
\hline Both pet and stray dogs & $(n=9) \quad 13$ & $(n=2) \quad 3$ & \\
\hline Don't know & $(n=27) 39$ & $(n=45) 64$ & $* *$ \\
\hline \multicolumn{4}{|l|}{$\begin{array}{l}\text { What types of dogs attack } \\
\text { domestic animals }\end{array}$} \\
\hline Owned/pet dog & $(n=5) \quad 7$ & $(\mathrm{n}=1) \quad 1.5$ & \\
\hline Stray dogs & $(\mathrm{n}=38) 55$ & $(n=24) 34$ & \\
\hline $\begin{array}{l}\text { Both pet and stray dogs } \\
\text { Don't know }\end{array}$ & $\begin{array}{ll}(\mathrm{n}=5) & 7 \\
(\mathrm{n}=22) & 31\end{array}$ & $\begin{array}{ll}(n=0) & 0 \\
(n=45) & 64.5\end{array}$ & $* * *$ \\
\hline
\end{tabular}

Note: Significance code $\left(\chi^{2}\right.$ test $):{ }^{*} P<0.01$, $* * * P<0.00$. 


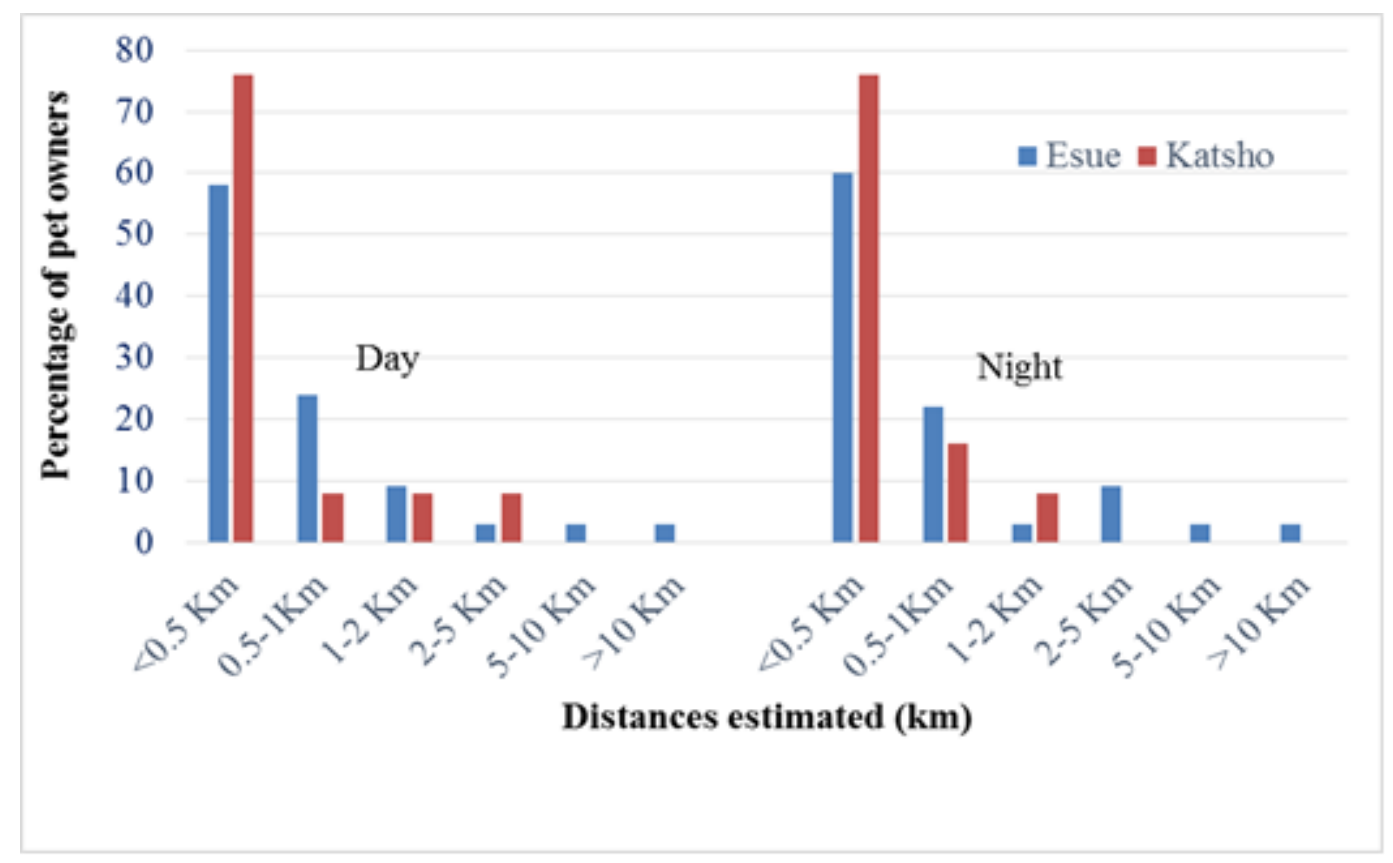

Figure 3. Owners' estimates of distances from homesteads travelled by pet dogs during the day or night in Esue $(n=35)$ and Katsho $(n=24)$.

\section{Local knowledge on dog diseases}

A total of 110 persons participated in the free-list exercise to explore local knowledge regarding dog diseases. On average, only two diseases names were given by individual respondents, and the maximum given was six diseases. In total, 28 different names of diseases have been cited by the participants, the number of diseases cited in Katsho rural area (18) being slightly higher than for the town respondents (12). Most disease names were given in the Dzongkha language, with few diseases names given in English, especially by respondents who had a high level of formal education (e.g. 'rabies', 'cyst', 'distemper' and 'parvo'). From the free list saturation curve, it appeared that 35 respondents would gather all the diseases named by the 110 participants. As indicated in Table 4, rabies (Choenoe) was by far the most salient item (highest Sutrop index value), cited most frequently by the participants (70\%) and with the highest rank in the lists. The next diseases names mentioned were Scabies/Koongnoe (Sutrop $=0.348$ ) and Transmissible Venereal Tumour/Semboto (Sutrop =0.075). Apart from rabies, which was known to be transmissible from dogs to humans, the potential risks of other dog disease transmission to humans or animals was largely unknown. On a few occasions, local folk epidemiology did not match conventional scientific knowledge. For example, a farmer woman from Katsho village indicated that out of her experience she believed that a 'cyst/tumor' affecting a human being could be transmitted to the dogs. 
Table 4. Most common names of dog diseases listed by interviewees in Esue and Katsho villages ( $\mathrm{n}=110$ participants). Only items mentioned by at least two different respondents are mentioned; with the original (Dzongkha) name given by the respondent, the corresponding putative veterinary name in English (based on symptoms and etiology), the frequency and average rank of citation, and the salience Sutrop Index (see text; (Pennec et al., 2014))

\begin{tabular}{llccc}
\hline $\begin{array}{c}\text { Original name/ } \\
\text { Dzongkha name }\end{array}$ & $\begin{array}{l}\text { Veterinary name of } \\
\text { Disease-Syndrome }\end{array}$ & Frequency & $\begin{array}{c}\text { Average } \\
\text { rank }\end{array}$ & $\begin{array}{c}\text { Sutrop } \\
\text { Index }\end{array}$ \\
\hline Choenoe & Rabies & $70.00 \%$ & 1.455 & 0.481 \\
Koongnoe & Scabies & $52.73 \%$ & 1.517 & 0.348 \\
& Transmissible & & & \\
Semboto & Venereal Tumor & $15.45 \%$ & 2.059 & 0.075 \\
Guyum & Gid/Coenurosis & $8.18 \%$ & 1.444 & 0.057 \\
Zakhamchoednoe & Anorexia & $4.55 \%$ & 3.000 & 0.015 \\
Puuboe & Alopecia & $4.55 \%$ & 3.200 & 0.014 \\
Chabsasha & Diarrhea & $3.64 \%$ & 3.500 & 0.010 \\
Maag & External Wound & $3.64 \%$ & 3.000 & 0.012 \\
Khaleychug & Vomit & $3.64 \%$ & 1.750 & 0.021 \\
Distemper & Canine Distemper & $3.64 \%$ & 2.500 & 0.015 \\
\hline
\end{tabular}

\section{Feral dogs}

Although the majority of respondents acknowledged the existence of feral dogs populations (64\%), only $40 \%$ reported having seen with their own eyes in the rural villages and $36 \%$ in the semi-urban area $\left(\chi^{2}=0.030146, \mathrm{df}=1, P=0.8\right)$. The possible origins mentioned of feral dogs were similar in Esue and Kastho $\left(\chi^{2}=4.6728, \mathrm{df}=3, P=0.19\right)$, including abandoned individually-owned pet dogs (64\% in Eusu and $49 \%$ in Katsho), abandoned community-owned stray dogs (17\% in Esue and $31 \%$ in Katsho) and only a minority of respondents believed that they were offspring of existing feral dog populations (3\% in Esue and 4\% in Katsho). During individual interviews, people mentioned that "stray dogs escape from human settlements to avoid catching during the CNVR campaigns" and "people deliberately release some of the puppies into the forest". Approximately 50\% of the respondents from both sites estimated that the feral dog populations in their areas have increased over the past five years $\left(\chi^{2}=5.9125\right.$, $\mathrm{df}=3, P=0.11)$.

\section{DISCUSSION}

Our study demonstrated that the people in Haa district have contrasted perceptions regarding pet, stray and feral dogs. People in Esue and Katsho villages classify dogs based on ownership and dependency to human into 'owned 
dogs' (Jodha yoeme) vs 'not owned dogs' (Jodha meyme), and secondarily introduced the difference between 'stray dog' (Chankhe) and 'feral dog' (Shakhe). The pet dogs were termed Gokhi ('door dog'). This classification is in agreement with the categorization of dogs proposed by other authors in other contexts (Slater et al., 2008; Blouin, 2013). However, it should be noted that the sub-classification 'feral' vs 'stray' was not reported spontaneously by interviewees during other surveys in Bhutan (Tenzin et al., 2011; Tenzin et al., 2017), and it may be associated with specific local conditions of our survey in Haa (i.e. proximity of protected area and large 'wilderness' pieces of land).

People in Haa emphasized the benefits they obtained from their dog companions, acknowledging their positive contributions to the well-being of the owners. When confronted with the eventual loss of their dogs, the great majority of respondents indicated that their happiness would be strongly affected, emphasizing the important emotional and psychological role that pet dogs play for rural communities in the area. The most commonly mentioned benefit for keeping pet dogs was the protection of agriculture crops, livestock and other properties. This echoes the benefits of common utility dogs documented in other agrarians areas (Coren, 2002) similar to Haa where more than half of the populations depends on agriculture and livestock for their livelihoods (PHCB Haa Dzongkhag, 2017).

Besides several positive outcomes of keeping pet dogs, people also emphasize on the negative outcomes of free-roaming dogs in both study sites. These negative impacts are mostly attributed to stray and feral dogs, which is also being described by other authors (Wierzbowska., 2016; Massei et al., 2017; dos Santos et al., 2018), although the respondents acknowledge that owned dogs mays be as destructive if they are not confined (Slater et al., 2008). These negative impacts of dogs are similar to those mentioned in other studies (Morters et al., 2014; Villatoro et al., 2018) including bites/attacks of humans or domestic and wild animals, transmission of diseases to human and wildlife, nuisance because of noise/barking, and environmental contamination with feces and urine.

One of the most striking results of our survey was the general fear of freeroaming dogs expressed by most people, in both the rural and semi-urban sites, especially by women and children. This situation is particularly problematic and calls for action in an area where people frequently walk long distances along roads and tracks (to school, crop fields, grazing areas, forest) and may encouter aggressive dogs. The fear of free-roaming dogs was also expressed by tourists visiting Bhutan (Strickland, 2015).

There are several costs associated with free-roaming dogs, including vaccination costs, post-bite treatment, loss of livestock and wildlife, and reduction in tourism revenues (Strickland, 2015). However, the perceptions of dog impacts among people living in Haa differed between rural and urban communities probably because farmers were most likely to be affected by freeroaming dogs through predation of livestock and agriculture crops, and 
environmental contamination. Dog associated risks of zoonotic disease transmission ranked high in the preoccupations of the participants in our survey in Haa, but it referred almost exclusively to a single disease (i.e. rabies), though there has not been any outbreak of rabies in the district. In contrast, people from both the rural and semi-urban sites acknowledged a limited knowledge regarding dog diseases and associated epidemiological risks.

Breed was not a major factor in determining the management of pet dogs by people in Haa, which differs from other areas around the world (Villatoro et al., 2018). For instance, dog reproduction, health and housing, which often differ according to the breed (Blouin, 2013), were similar for cross-breeds, local Mastiff, and imported pure breeds. In both study areas, the majority of the pet dogs are being spayed/neutered and vaccinated against rabies through Catch Neuter Vaccinate and Release/Community Animal Birth Control program, despite some reservations linked with religious belief (Rinzin, 2015). Besides rabies, the majority of owners in Haa had not vaccinated or treated their dogs against any common infectious canine diseases, which could indicate a poor awareness of canine infectious diseases and zoonotic diseases, or prohibitive costs for the vaccines/treatments, as we believe that most of the persons interviewed would care for their animal welfare if properly informed. Similarly, we found that a large portion of dog owners would do nothing when their pet dog was sick, although some owners seek treatment from conventional veterinary medicine. Interestingly, although local spiritual healers and astrologist acknowledge the fact that dog may suffer from magical causes of diseases, they are apparently never approached for treating dogs magically, unlike cattle.

Community members from both study areas indicated that free-roaming dogs directly interact with wildlife, especially with wild pigs, barking deer, and sambar deer. According to the informants, these direct interactions between wildlife and dogs happen mostly when the wild animals enter the crop fields, and hence the interactions were mostly located at the periphery of the village settlement and inside or near the crop fields. These results suggest that freeroaming dogs have direct negative impacts on wildlife, confirming the conclusions of numerous several studies across the world (Young et al., 2011; Sepúlveda et al., 2015; Lessa et al., 2016; Zapata-Ríos and Branch, 2016), while also emphasising the key role played by domestic dogs in the the mitigation of human-wildlife conflicts.

\section{CONCLUSION}

This study has shown that the awareness level about rabies among respondents was high in both rural and town communities of Esue and Katsho geogs. However, despite the presence of active veterinary programs, the awareness of people regarding dog diseases and the potential epidemiological risks of transmission to people and wildlife was limited. Similarly, despite the 
proximity of an important Nature Reserve and while reporting occasional direct interactions between dogs and wildlife, the awarness regarding ecological risks associated with uncontrolled free-roaming dogs was low. Most negative impacts of dogs were attributed to stray and feral dogs, and the majority of people calls for population control and dog confinement for owned dogs. Therefore, it is timely for the government, research and associations to focus on improved control methods for stray and feral dogs, while widening the scope of investigations apart from rabies, to other dog diseases that may threaten public, veterinary and wildlife health. In particular, the Department of Forest and Park services should also focus on disease surveillance in wildlife, in order to monitor for possible spill-over and spill-back infections from/to free-roaming dogs.

\section{REFERENCES}

Acosta-Jamett, G., Surot, D., Cortés, M., Marambio, V., Valenzuela, C., Vallverdu, A., and Ward, M.P. 2015. Epidemiology of canine distemper and canine parvovirus in domestic dogs in urban and rural areas of the Araucanía region in Chile. Veterinary Microbiology. 178(3): 260-264. https://doi.org/10.1016/j.vetmic.2015.05.012

Blouin, D.D. 2013. Are dogs children, companions, or just animals? Understanding variations in people's orientations toward animals. Anthrozoös. 26(2): 279-294. https://doi.org/10.2752/175303713X13636 846944402

Boitani, L., and Ciucci, P. 1995. Comparative social ecology of feral dogs and wolves. Ethology Ecology \& Evolution. 7(1): 49-72. https://doi.org/10. 1080/08927014.1995.9522969

Borgatti, S.P. 1999. Elicitation techniques for cultural domain analysis. In: Schensul, J., and LeCompte, M., editors. The Ethnographer's toolkit (Schensul J., LeCompte M.). Walnut Creek. CA: Altamira Press. p. 1-26.

Choden, T. 2016. An evaluation of the effectiveness of a protected area management model in Bhutan: a case study of Phrumsengla National Park, Central Bhutan. (Other, Murdoch University). Retrieved from http://researchrepository.murdoch.edu.au/id/eprint/35824/

Coren, S. 2002. The pawprints of history: dogs in the course of human events. NY: Free Press.

Czupryna, A.M., Brown, J.S., Bigambo, M.A., Whelan, C.J., Mehta, S.D., Santymire, R.M., and Faust, L.J. 2016. Ecology and demography of freeroaming domestic dogs in rural villages near Serengeti National Park in Tanzania. PLOS ONE. 11(11): e0167092. https://doi.org/ 10.1371/journal. pone.0167092

Dexter, F. 2013. Wilcoxon-Mann-Whitney test used for data that are not normally distributed. Anesthesia \& Analgesia. 117(3): 537. https://doi.org/10.1213/ ANE.0b013e31829ed28f 
Dorji, S., Vernes, K., and Rajaratnam, R. 2011. Habitat correlates of the red panda in the temperate forests of Bhutan. PLoS ONE. 6(10): e26483. https://doi. org/10.1371/journal.pone.0026483

dos Santos, C.L.A., Le Pendu, Y., Giné, G.A.F., Dickman, C.R., Newsome, T. M., and Cassano, C.R. 2018. Human behaviors determine the direct and indirect impacts of free-ranging dogs on wildlife. Journal of Mammalogy. 99(5): 1261-1269. https://doi.org/10.1093/jmammal/gyy077

du Prel, J.-B., Röhrig, B., Hommel, G., and Blettner, M. 2010. Choosing statistical tests. Deutsches Ärzteblatt International. 107(19): 343-348. https://doi.org/10.3238/arztebl.2010.0343

Goodman, L.A. 1961. Snowball sampling. The Annals of Mathematical Statistics. 32(1): 148-170.

Hughes, J., and Macdonald, D.W. 2013. A review of the interactions between free-roaming domestic dogs and wildlife. Biological Conservation. 157(Supplement C): 341-351. https://doi.org/10.1016/j.biocon.2012.07. 005

Larson, G., and Burger, J. 2013. A population genetics view of animal domestication. Trends in Genetics. 29(4): 197-205. https://doi.org/10. 1016/j.tig.2013.01.003

Lessa, I., Corrêa Seabra Guimarães, T., de Godoy Bergallo, H., Cunha, A., and M. Vieira, E. 2016. Domestic dogs in protected areas: a threat to Brazilian mammals? Natureza \& Conservação. 14(2): 46-56. https://doi.org/10. 1016/j.ncon.2016.05.001

Macpherson, C.N.L., Meslin, F.-X., and Wandeler, A.I. 2000. Dogs, Zoonoses, and Public Health. CABI.

Massei, G., Fooks, A.R., Horton, D.L., Callaby, R., Sharma, K., Dhakal, I.P., and Dahal, U. 2017. Free-roaming dogs in Nepal: demographics, health and public knowledge, attitudes and practices. Zoonoses and Public Health. 64(1): 29-40. https://doi.org/10.1111/zph.12280

Morters, M. K., Bharadwaj, S., Whay, H.R., Cleaveland, S., Damriyasa, I.M., and Wood, J.L.N. 2014. Participatory methods for the assessment of the ownership status of free-roaming dogs in Bali, Indonesia, for disease control and animal welfare. Preventive Veterinary Medicine. 116(1): 203208. https://doi.org/10.1016/j.prevetmed.2014.04.012

Pennec, F., Raimond, C., Bohbot, H., Pennec, F., Wencélius J., and Garine, E. 2014. FLAME 1.1 Free-List Analysis under Microsoft Excel (Version 1.1) [English].

PHCB Haa Dzongkhag. 2017. Population and housing census of Bhutan, Haa Dzongkhag. Retrieved from http://www.nsb.gov.bt/publication/files/ PHCB2017_Haa Dzongkhag

Rinzin, K. 2015. Population dynamics and health status of free-roaming dogs in Bhutan [dissertation]. [Western Australia]: Murdoch University. 
R core Team. 2017. R: A language and environment for statistical computing. Vienna, Austria: R Foundation for Statistical Computing; 2017. https:// www. R-project.org.

Sepúlveda, M., Pelican, K., Cross, P., Eguren, A., and Singer, R. 2015. Fine-scale movements of rural free-ranging dogs in conservation areas in the temperate rainforest of the coastal range of southern Chile. Mammalian Biology - Zeitschrift Für Säugetierkunde. 80(4): 290-297. https://doi.org/ 10.1016/j.mambio.2015.03.001

Slater, M.R. 2004. Understanding issues and solutions for unowned, free-roaming cat populations. Journal of the American Veterinary Medical Association. 225(9): 1350-1354. https://doi.org/10.2460/javma.2004.225. 1350.1

Slater, M.R., Di Nardo, A., Pediconi, O., Villa, P.D., Candeloro, L., Alessandrini, B., and Del Papa, S. 2008. Cat and dog ownership and management patterns in central Italy. Preventive Veterinary Medicine. 85(3): 267-294. https://doi.org/10.1016/j.prevetmed.2008.02.001

Strickland, P.C. 2015. It's a dog's life: international tourists' perceptions of the stray dog population of Bhutan. Journal of Arts and Humanities. 4(12): 0111. https://doi.org/10.18533/journal.v4i12.856

Tenzin, Dhand, N.K., Gyeltshen, T., Firestone, S., Zangmo, C., Dema, C., and Ward, M.P. 2011. Dog bites in humans and estimating human rabies mortality in rabies endemic areas of Bhutan. PLOS Neglected Tropical Diseases. 5(11): e1391. https://doi.org/10.1371/journal.pntd.0001391

Tenzin, Dhand, N.K., and Ward, M.P. 2012. Anthropogenic and environmental risk factors for rabies occurrence in Bhutan. Preventive Veterinary Medicine. 107(1): 21-26. https://doi.org/10.1016/j.prevetmed.2012.05. 003

Tenzin, T., Namgyal, J., and Letho, S. 2017. Community-based survey during rabies outbreaks in Rangjung town, Trashigang, eastern Bhutan, 2016. BMC Infectious Diseases. 17: 281. https://doi.org/10.1186/s12879-0172393-x

Tenzin, Dhand, N.K., and Ward, M.P. 2012. Review of rabies epidemiology and control in South, South East and East Asia: past, present and prospects for elimination. Zoonoses and Public Health. 59(7): 451-467. https://doi.org/ 10.1111/j.1863-2378.2012.01489.x

Villatoro, F.J., Naughton-Treves, L., Sepúlveda, M.A., Stowhas, P., Mardones, F.O., and Silva-Rodríguez, E.A. 2018. When free-ranging dogs threaten wildlife: public attitudes toward management strategies in southern Chile. Journal of Environmental Management. 229(1): 67-75. https://doi.org/10.1016/j.jenvman.2018.06.035

Ward, A.I., Dendy, J., and Cowan, D.P. 2015. Mitigating impacts of roads on wildlife: an agenda for the conservation of priority European protected species in Great Britain. European Journal of Wildlife Research. 61(2): 199-211. https://doi.org/10.1007/s10344-015-0901-0 
Wierzbowska, I.A., Hędrzak, M., Popczyk, B., Okarma, H., and Crooks, K.R. 2016. Predation of wildlife by free-ranging domestic dogs in Polish hunting grounds and potential competition with the grey wolf. Biological Conservation. 201(Supplement C): 1-9. https://doi.org/10.1016/ j.biocon. 2016.06.016

Winkle, M., Crowe, T.K., and Hendrix, I. 2012. Service dogs and people with physical disabilities partnerships: a systematic review. Occupational Therapy International. 19(1): 54-66. https://doi.org/10.1002/oti.323

Woodward, W. 2001. Dog stars and dog souls : the lives of dogs in Triomf by Marlene van Niekerk and Disgrace by J.M. Coetzee. Journal of Literary Studies. 17(3-4): 90-119.https://doi.org/10.1080/0256470108530279

Young, J.K., Olson, K.A., Reading, R.P., Amgalanbaatar, S., and Berger, J. 2011. Is wildlife going to the dogs? Impacts of feral and free-roaming dogs on wildlife populations. BioScience. 61(2): 125-132. https://doi.org/ 10.1525/bio.2011.61.2.7

Zapata-Ríos, G., and Branch, L.C. 2016. Altered activity patterns and reduced abundance of native mammals in sites with feral dogs in the high Andes. Biological Conservation. 193(Supplement C): 9-16. https://doi.org/ 10.1016/j.biocon.2015.10.016 